\title{
The Effectiveness of Project-Based Learning in a Skirt Making Skill for Deaf Students
}

\author{
Firma Dina, Jon Efendi \\ Universitas Negeri Padang, Indonesia \\ firmadina111@gmail.com, jonefendi@,fip.unp.ac.id
}

\begin{tabular}{|c|c|c|}
\hline Accepted: & Reviewed: & Published: \\
Feb $10^{\text {th }} 2020$ & April 5 $5^{\text {th }}, 2020$ & May,30th 2020 \\
\hline
\end{tabular}

\begin{abstract}
Starting from the preliminary study conducted by the authors at the SLB Perwari and found the condition where the deaf students of grade $\mathrm{X}$ have not been able to make a skirt that became one of the materials in the vocational learning curriculum for the class, one of his students is the teacher has not found and used the right method to teach the material. Then the author is motivated to prove one of the methods of learning, which is a project-based learning method, whether the method has an effect on learning the material. With experimental research methods and pre-experimental design of one group pre-test post-test, the author performs a stage of research starting from the initial test, then administering the treatment, then the final test. While the tools used in collecting data is a proven instrument that is valid and reliable. The results of the initial test scores and the final tests were then calculated by statistical tests using Wilcoxon's signed ranks test (Wilcoxon matched pairs) formula and the resulting results where the value of ASYMP. The Sig. (2tailed) is smaller than the significant level value.
\end{abstract}

Keywords: Project-based learning, skirts, deaf students

\section{Introduction}

Independence becomes one of the points of interest in addition to academic ability in the achievement of the education process, it is also mentioned in the law as one of several aspects of education objectives. The ability to live independently, such as financial independence is required by everyone, because it everybody wants to have a capacity that can make them can have a good job and can compete with the community in general as well as disability, with the obstacles they have nonetheless they need to have the capacity to live independently, have a decent work and able to compete with the general public. 
In 2017 there were about 400 thousands of the number of disabilities entered in the data on the amount of Unemployments ${ }^{1}$. It is a data that is very much a disability that has not been able to be independent especially in terms of financial, because it is not easy for a disability to get a good job, given the obstacles that have and must compete with non-disability job seekers. Therefore, it must be a disability to have capacity that can help and facilitate them to have a job, even open the job itself. Disabilities require proficiency or skills which will be a provision for them in the face of transition and continuing life.

Life skills such as vocationals can usually be obtained in formal schooling, can also be educated non-formal, private education and so on. As found by the author in one of the extraordinary schools of SLB Perwari Padang, there students taught various skills such as art, computer, fashion, etc. In understanding the learning materials are good in the learning of the lessons, it takes not only the facilities, but also the learning methods that suit students for the learning.

Based on the results of preliminary study that the author did in the SLB Perwari Padang, is found that the school has potential with facilities and good motivation from teachers, only about learning methods that if it can improve the capacity and creativity of students, still not used or found by teachers, for example in the study of fashion for the deaf students of class X, teachers have not found the method that is felt according to the learning, and so far the students are still limited to learning how to sew or run a sewing machine, while in making the student's product need to understand from the preparation stage to the completion so that students can apply it outside the class and these skills can be a provision for them.

Deaf students, or also called hearing barriers, are students who have problems with their debiting conditions. A situation that makes one incapable of hearing and understanding the voice surrounding it ${ }^{2}$. These barriers affect students in attitudes, living the daily activities included in learning, but that does not mean deaf students cannot learn. Deaf students can receive information by focusing on their visuals, so students can learn more about it as long as we are able to reduce

\footnotetext{
${ }^{1}$ Nuraini R, "Catatan Pemerintah, Sebanyak 414.222 Penyandang Disabilitas Butuh Kerja," Jaringan Pemberitaan Pemerintah, April 2018.

2 Jamaris Martini, ANAK BERKEBUTUHAN KHUSUS (Bogor: Ghalia Indonesia, 2018).
} 
misunderstanding or misperception during learning ${ }^{3}$. As for the method of the drilling which also becomes one of the things that can encourage the achievement of learning objectives must be observed.

So many learning methods that can be applied to one of them are project-based learning, the core of this modern learning method is to connect the school life with the experience students have and influence students to think seriously as to learn something new ${ }^{4}$. There are several advantages to this learning method that makes this method deemed necessary to be treated. Then see from the background of the author as a graduate SMK majoring in fashion motivated writers to prove the effectiveness of this project-based learning method on skirt-making skills for students of the deaf Xgrade.

\section{Methods}

This research is related to research with quantitative approaches and experimental research methods, the purpose of the method is to see the effect of a treatment. , while for the design of the research to be used is pre-experimental. This pre-experimental design also consists of several types such as one-shot case study, one group Pretest-Posttest and Intec-group comparison, and which will be used in this research that is type one group Pretest-Posttest, which from its name we can know that there will only be one group without comparison. According to the type of research used, there are three stages in the research process that is assessment before receiving treatment (pretest), treatment (treatment), and measurements after obtaining treatment (posttest).

The variables in this study were two, one depend variable and one free variable, which became a free variable in the study was a project-based learning method while the company variables were skirt-making skills. Research conducted in the SLB Perwari Padang within a period of several weeks or approximately 2 months, can be on Monday to Saturday during the lesson hours after the breaking hour, with a sample of research consisting of five people, two women and three men with the same classification that is both $\mathrm{X}$ class and the same obstacles that are obstacles to the hearing.

\footnotetext{
${ }^{3}$ Hendra Jaya, Sapto Haryoko, and Sutarsi Suhaeb, "Life Skills Education for Children with Special Needs in Order to Facilitate Vocational Skills Life Skills Education for Children with Special Needs in Order to Facilitate Vocational Skills" (2018).

4 Douladeli Efstratia, "Experiential Education through Project Based Learning," Procedia - Social and Behavioral Sciences 152 (2014): 1256-1260.
} 
The data on the research will be gathered with test techniques that form performance tests, while the tools used to collect the data are instruments. Prior to use, the instrument must first be ascertained valid and reliable, evidenced by the validity and reusability test, the validity test is used to assess whether the instrument can measure the object, the variable, or the behavior to be researched. The validity and reusability test was done by the author in the SLB YPPLB Padang against 5 deaf students with the same classification of class $\mathrm{X}$ and the similarity of barriers that have the obstacles to the hearing. Once the validity and reusability value is obtained from the calculation using the product moment correlation formula for validity, and the Alpha formula for reusability, then the instrument can be used in the research. The following product moment and alpha formulas are used to calculate the validity and reusability values:

Correlation formula of Product Moment:

$$
r_{x y}=\frac{n \sum x y-\left(\sum x\right)(\Sigma y)}{\sqrt{\left\{n \sum x^{2}-\left(\sum x\right)^{2}\right\}\left\{n \sum y^{2}-(\Sigma y)^{2}\right\}}}
$$

Description:

rxy $=$ number index correlation " $\mathrm{T}$ " product moment

$\mathrm{n}=$ Number of cases

$\Sigma \mathrm{xy}=$ number of multiplication results between $\mathrm{x}$ score and $\mathrm{Y}$ score

$\Sigma \mathrm{x}=$ Sum of the whole score $\mathrm{X}$

$\Sigma_{\mathrm{y}}=$ sum of all Y scores

While the Alpha formula:

$$
r_{11}=\left(\frac{k}{k-1}\right)\left(1-\frac{\sum \sigma_{b}^{2}}{\sigma^{2} t}\right)
$$

Description:

R11 = Instrument Reliability

$\mathrm{K}=$ Number of items 


\section{$=$ Sum of grain variances \\ $=$ Total Variance}

The result of the calculation using the above two formulas is obtained 46 items that are declared valid from a total of 50 grains, and obtained a coefficient of $>0.70$ which means the instrument is determined to be reliable. Furthermore, the instrument can already be used in research to collect data, and the data is later tested with statistical tests using a formula that corresponds to the type of data collected, which in this research the formula to be used is the formula Wilcoxon signed ranks test.

\section{Results and Discussion}

In the previous point it was mentioned that there were three stages or procedures of research conducted in this study, starting from the initial test (pre-test) that assesses the ability before receiving treatment, then giving treatment (treatment) where the assessment stage was not carried out, and then final test (post-test) assessment after receiving treatment. The results of the assessment of each student on the initial test and final test are contained in the following table:

\section{Table 1 Initial Test (pre-test) and Final Test (post-test)}

\begin{tabular}{|l|c|c|c|}
\hline No & Student name & Pretest Value $\left(\mathrm{P}^{1}\right)$ & Post-test Value $\left(\mathrm{P}^{2}\right)$ \\
\hline 1. & $\mathrm{R}$ & 21.7 & 85.9 \\
\hline 2. & $\mathrm{~T}$ & 17,4 & 73,9 \\
\hline 3. & $\mathrm{~A}$ & 15.2 & 64.1 \\
\hline 4. & $\mathrm{D}$ & 19,6 & 67,3 \\
\hline 5. & $\mathrm{~B}$ & 17.4 & 70.6 \\
\hline
\end{tabular}


Looking at the comparison between the two values, it can be seen in the following graphic presentation:

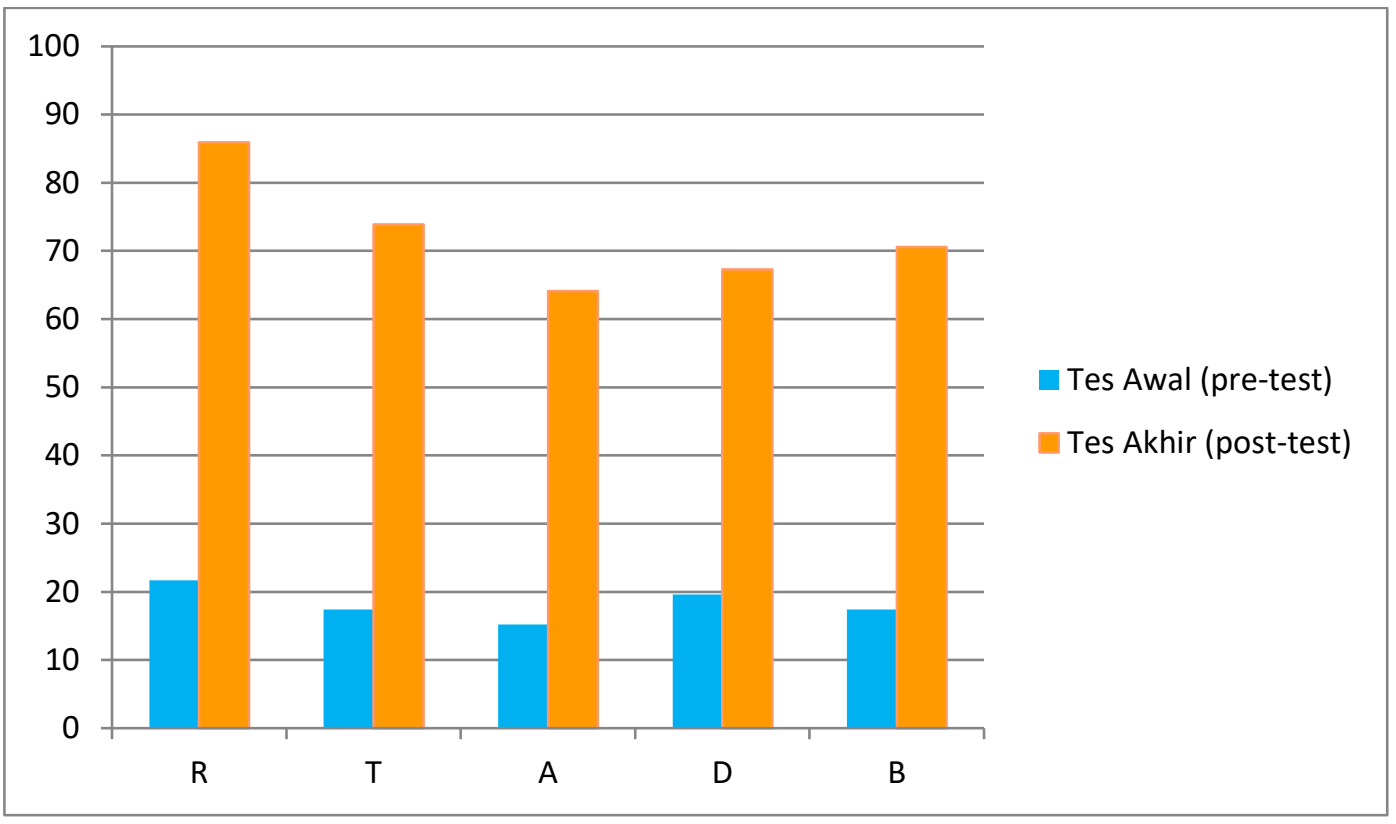

Not finished until there, the next statistical test is performed to process these values. Because this study belongs to non-parametric statistics and matches the type of data obtained, the formula used is the Wilcoxon signed ranks test. The test is used in testing the hypothesis that has two samples related to the form of data obtained is the type of ordinal data [1]. The calculation of the Wilcoxon test formula can be done using the SPSS16 application, and from these calculations we get the following results:

Table 2 Descriptive initial test scores (pre-test) and final test scores (post-test)

\begin{tabular}{|c|c|c|c|c|c|}
\hline & N & Minimum & Maximum & Mean & Std. Deviation \\
\hline pre-test & 5 & 15 & 21 & 17.80 & 2,280 \\
\hline
\end{tabular}




\begin{tabular}{|c|c|c|c|c|c|}
\hline Valid N (listwise) & 5 & & & & \\
\hline post-test & 5 & 64 & 85 & 71.80 & 8.106 \\
\hline Valid N (listwise) & 5 & & & & \\
\hline
\end{tabular}

The table above is a descriptive initial test score and final test where it can be seen in the initial test that the highest score is 21 , the lowest score is 15 , the average score is 17.8 , and the standard deviation is 2,280. While the final test scores the highest scores obtained were 85 , the lowest scores were 64 , the average was 71.8 and the standard deviation was 8.106. Furthermore, there is also a rank or difference between the two values, the results are as follows:

Table 3 Rank the value of the initial test (pre-test) final test (post-test)

\begin{tabular}{|c|c|c|c|c|}
\hline \multicolumn{3}{|c|}{ Ranks } \\
\hline & \multicolumn{2}{|c|}{ N } & Mean Rank & Sum of Ranks \\
\hline post-test - pre-test & Negative Ranks & $0^{\mathrm{a}}$ & .00 & .00 \\
\cline { 2 - 5 } & Positive Ranks & $5^{\mathrm{b}}$ & 3.00 & 15.00 \\
\cline { 2 - 5 } & Ties & $0^{\mathrm{c}}$ & & \\
\cline { 2 - 5 } & total & 5 & & \\
\hline a. post-test $<$ pre-test & & & \\
\hline b. post-test $>$ pre-test & & & \\
\hline c. post-test $=$ pre-test & & & \\
\hline
\end{tabular}


In the rank table above explains that the negative difference of the two values namely the initial test value and the final test is 0, both on N, Mean Rank, and Sum of Ranks. Then on the positive difference obtained 5 positive data for the value of $\mathrm{N}$, the meaning of the 5 students both experienced an increase in grades, while the average value of the increase was 3 , and the number of positive rankings was 15 , for Ties that obtained a value of 0 can be interpreted that the value of the two tests have nothing in common. The next calculation result is a statistical test, following acquisition:

Table 4 Statistic test the value of the initial test (pre-test) final test (post-test)

\begin{tabular}{|c|c|}
\hline \multicolumn{2}{|c|}{ Test Statistics $^{\text {b }}$} \\
\hline Z- & post-test - pre-test \\
\hline Asymp. Sig. (2-tailed) & 0.043 \\
\hline a. Based on negative ranks. \\
\hline b. Wilcoxon Signed Ranks Test \\
\hline
\end{tabular}

From the above statistical test table,known Asymp is. Sig. (2-tailed) or the calculated probability value is 0.043 while the significance level is $5 \%$ or 0.05 . Comparison of the value of the probability of the test results with a significant level value will determine the decision of the hypothesis obtained. Before making a hypothesis decision, it is necessary to know the basis for the recovery of the hypothesis decision from the Wilcoxon test results: 
Table 5 Basic Table of HypothesisDecision Making

\begin{tabular}{|c|c|c|c|}
\hline HypothesisHypothesis & $\begin{array}{c}\text { Asym. (2- } \\
\text { tailed) }\end{array}$ & $\begin{array}{c}\text { Sig. Significant } \\
\text { level }(\alpha)\end{array}$ & Conclusion \\
\hline $\begin{array}{l}\text { Ho: } \\
\text { Project-based learning is not effective in making } \\
\text { skirt skills for class } \mathrm{X} \text { deaf students in Perwari } \\
\text { PadangSLB } \\
\text { Ha: } \\
\text { Project-based learning is effective in making skirt } \\
\text { skills for class X deaf students in SLB Perwari Padang }\end{array}$ & $>0.05$ & 0.05 & $\begin{array}{c}\text { Ho } \\
\text { Ha is } \\
\text { rejected }\end{array}$ \\
\hline & $<0.05$ & & $\begin{array}{c}\text { Horejected } \\
\mathrm{Ha} \text { is }\end{array}$ \\
\hline
\end{tabular}

Seeing the comparison of the results of statistical tests where the probability value of the test results obtained 0.043 while the value of the significant level is 0.05 , it is known that the probability of the results of the test results or Asymp. Sig. (2-tailed) is smaller than the significance level or $(0.043$ $<0.05)$. Based on Table 5 the decision can be made that $\mathrm{Ha}$ is accepted, meaning that project-based learning is effective in making skirts for class X deaf students in Perwari Padang SLB.

\section{Conclusion}

The above exposure and discussion resulted in the conclusion that from the research conducted, data calculation results in statistical tests with the formula Wilcoxon obtain a lower calculated value of 0.043 of its significance is 0.05 and from the acquisition can be taken a hypothesized decision or concluded that Ho rejected while Ha accepted, meaning that the method 
of teaching-based learning is effective in skirt-making skills for students who are deaf class X in SLB Perwari Padang.

\section{REFERENCES}

Akunto Suharsimi. PROSEDUR PENELITIAN. Jakarta: Rineka Cipta, 2013.

Efstratia, Douladeli. "Experiential Education through Project Based Learning." Procedia - Social and Behavioral Sciences 152 (2014): 1256-1260.

Jamaris Martini. ANAK BERKEBUTUHAN KHUSUS. Bogor: Ghalia Indonesia, 2018.

Jaya, Hendra, Sapto Haryoko, and Sutarsi Suhaeb. "Life Skills Education for Children with Special Needs in Order to Facilitate Vocational Skills Life Skills Education for Children with Special Needs in Order to Facilitate Vocational Skills” (2018).

Misbahuddin, and Iqbal Hasan. Analisis Data Penelitian Dengan Statistik. 2nd ed. Jakarta: PT Bumi Aksara, 2014.

Nuraini R. “Catatan Pemerintah, Sebanyak 414.222 Penyandang Disabilitas Butuh Kerja.” Jaringan Pemberitaan Pemerintah, April 2018.

Ridwan Abdullah Sani, Sondang R Manurung, Hary Suswanto, and Sudiran. PENELITIAN PENDIDIKAN. Tanggerang: Tsmart Printing, 2018.

Sugiyono. Metode Penelitian Pendidikan. Bandung: ALFABETA, 2016.

Yusuf A Muri. METODE PENELITIAN: KUANTITATIF, KUALITATIF, DAN PENELITIAN GABUNGAN. Jakarta: PRENADAMEDIA GROUP, 2016.

Metode Penelitian Kuantitatif, Kualitatif \& Penelitian Gabungan. Jakarta: PRENADAMEDIA GROUP, 2016. 